NYPL RESEARCH LIBRARIES

||

3 3433082370952 



\section{,}

.

4

- 


Digitized by the Internet Archive in 2008 with funding from Microsoft Corporation 


\title{
THE TEACHINGS OF
}

\section{THOMAS HENRY HUXLEY}

\author{
BY \\ IRVING WILSON VOORHEES
}

M. S. (PRINCETON) M. D. (COLUMBIA)

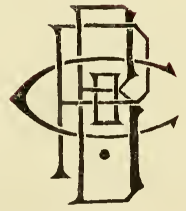

BROADWAY PUBLISHING CO.

NEW YORK

1907 


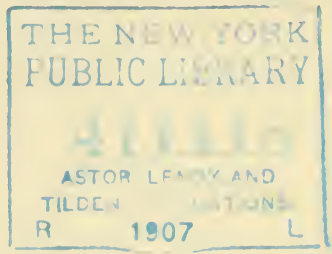

Copyright, 1907.

B Y

IRVING WII.SON VOORHEES

$\because \because \because \because \because \because \because \quad \vdots \quad \because \cdots \because$, All Rights Rescrved.

$\because \because \because \because \because \cdots \div \because$

$\because \vdots \vdots \because \because \vdots: \because \because$

$\because \because \ldots \therefore \div \div: \because$

$\because \because \because \therefore \because \because \because \because \vdots$

$\because \because \therefore \therefore \div$ 
To

Henry van Dyke

Teacher of Literature and Life

Lover of Plitosophy and Friendship

This Book is Gratefully Inscribed by his former Pupil the Author 



\section{CONTENTS.}

\section{FOREWORD.}

PART I.

The Man.

PART II.

His Teachings.

-I-Biological Teachings.

II-Theological Teachings.

-III-Educational Teachings. "

IV-Moral Teachings.

v-Teachings Concerning the Gospel of Work.

vI-Teachings Concerning Individual Rights.

-viI-Psychological Teachings. 



\section{FOREWORD}

The purpose of a life, the central idea about which all its activities revolve must ever be the criterion by which posterity shall judge of its efficiency. It is not how much nor how well nor yet how ill the work has been done, but Why was it done? The motif of an act is often all that is required to recommend or to condemn it at once. If the motif was bad the results can scarcely be other than bad; and if the motif be good the end-results can be criticized only from the standpoint of comparative worth. Many a good thought or act has been spoiled in the making or the doing; but a bad thought or act can never be made over into goodness by any process of juggling or craft. It is conceived in death and destruction at the very outset.

There is, then, a cardinal rule of criticism in letters as in life which one may use as a sort of qualification test to determine 
the legitimacy of an author as the parent of his idea. Was he honest and sincere? Was his object worthy of the effort? These two questions are basic in any argument concerning the value of literary achicvement.

We are exceedingly fortunate in having preserved for us so many of the details of Huxley's life. Tho often a man of science is known only by what he does, or rather by what he is able to make people think he does, and not at all by what he is. I do not believe there is or ever will be any question as to Huxley's fitness, earnestness and superlative adaptability for the hard tasks which he voluntarily set for himself. $H$ is was a mind untrammeled by bigotry, conceit or love of self-amgrandizement. There was nothing of the hysteric or bizarre in his nature. He liver a perfectly natural, thought-free, conscientious daily round. As for his objective point, it was circumscribed by two all-embracing principles-betterment of mankind and the advancement of knowledge. In proof of this it is only necessary to remember that 
he never declared his bonnes raisons from the housetops-a symptom which so often makes the diagnosis of grand-stand mania an easy one. One may not, one can not agree with Huxley in everything. To the deeply religious his views are at times intolerable, but they can never be assailed on the ground of failing manly courage nor as the mawkish expressions of an ill-balanced intellect. 



\section{The Teachings of Thomas Henry Huxley}

\section{PART I.}

\section{THE MAN.}

In the bestowal of her gifts Nature is often accused of the most unequivocal partiality. This, of course, on the part of those who imagine themselves to have been slighted by the gentle Benefactress, and who, in the absence of any degree of success in their various callings, choose to find a cause in the uncontrollable, rather than in those material affairs which lie close at hand and for which Man is himself directly responsible. I would not have it inferred from this that Nature is not at all responsible for success in life as viewed by our human sense or that "Every man is the architect of his own fortune," as the old debating societies used to phrase it; nor do I believe the equally unreasonable dictum of Rousseau that "All men are created free and equal"-a doctrine so ably combated by the subject of this sketch. There are, however, men of great at- 
trinments whom all the world delights to honor lecause of a seeming emancipation from the laws of time and space which limit the capacity of ordinary mortals and cause their names to be "writ in water." Such an one was Thomas Henry IIuxley, who, though burdened with an always failing health, was possessed of such remarkable versatility that he found time to become an expert in many lines of scientific inquiry, and who made frequent excursions into fields of literary and general culture as well, always returning with baskets laden with rich fruit plucked from every prolific branch within reach of his path. His was truly the versatility of genius, a type quite distinct from that other which passes under the name of versatility and which in these later days belongs distinctly to the "Smart Set," who, like 'Talleyrand's physician, know a little of everything, "Even a little physic."

It seems to me that two main forces wero at work throughout Huxley's life: the one that of the scientific investigator full of enthusiasm, dominant, persevering, toiling arduously day by day in the laboratory, discovering new facts and placing them aside for future use, and testing scientific theories to make sure that there was no mistaken hypothesis which might mislead in using it as a basis for further conclusions. The other was that of the polemical philosopher, fond of arguments, combative, 
alert to find a weak spot or opening in his opponent's defence, fighting ever like a good swordsman partly for victory, partly for the upholding of what he deemed a principle or ideal worthy of the strife. It would be invidious to draw too close a differential between these, although there can be scarcely a doubt which was more beneficial to his fellow-men, because both had a common basis which lay instinctive, hidden, even perhaps to himself, yet forming woof and fiber of his very being, viz., the love of Truth. This was the chief purpose in every thought and deed-to know the right, to follow it oneself, and to teach it to others. For him as for the lamented Keats,

"Beauty is truth, truth beauty-that is all Ye know on earth, and all ye need to know." *

It is not my purpose to write either a eulogium or a criticism of Huxley-the former would be useless, the latter presumptuous. Nor do I intend to give a detailed account of daily sayings and doings-a function which belongs to the biographer or literary executor rather than to the appreciator who merely tries to give his impressions, duly weighed and considered after a careful reading of the personal record of his mentor. Perhaps, however, a

* Ode on a Grecian urn. 
brief resumè of Huxley's early life will not he amiss as enabling us to follow more closely the trend of his thoughts and the purposes by which he was actuated.

Thomas Henry Huxley first saw the light at Ealing, at that time a country village but since grown to be a suburb of London, on May 4th, 1825. He remarks humorously that "The windows of my mother's room were open in consequence of the unusual warmth of the weather. For the same reason, probably, a neighboring beehive had swarmesl, and the new colony pitching on the window-sill was making its way into the room when the horrified nurse shut down the sash. If that well-meaning woman had only abstained from her ill-timed interference, the swarm might have settled on my lips, and I should have keen endowed with that melliflunus eloquence which, in this country, leads far more surcly than worth, capacity or honest work, to the highest places in Church and State." *

His early childhood seerns to have been of the ordinary sort, but he posseseses eertain inherited characteristics which make him different from his playmates. From his father, who was, by the way, a master in a semi-public

*Autohiography. "Method and Results". in Collected Essays by 'T. H. Huxley. Vol. I. I) Appleton, is? . 
school of the town, came a talent for drawing, a rather ungovernable temper, and a fondness for dispute which bordered closely on the $a b-$ stinate. His mother gets most of the credit for passing on her good traits, which were: an excellent mental capacity, force of character, energy, and rapidity of thought, which latter sometimes "played him sad tricks and was always a danger," but which he would not have parted with at any cost. For some reason his school training" was brief, he "studied himself," an ambiguity which contains a paradox of truth, meaning that he was wholesomely introspective, and grasping enough to understand things without the aid of a teacher. A fondness for mechanies led him to take up electricity in a desultory fashion, while a desire to know something of the functions of the human body introduced him to the basic subject of later scientific work, viz., Physiology as taught by Mr. Wharton Jones at the Char. ing Cross School of Medicine, a man who was extremely kind and helpful to the youthful student, and who made a lasting impression by the extent and precision of his knowledge. About this time Huxley began to study German and soon became so proficient that he read withont the least difficulty the latest advances in scientific thought as given in the periodical literature of that tongue. Carlyle was an early favorite and doubtless contrib- 
uted a share of mental pabulum that strengthened permanently the mind of the omnivorous reader. In metaphysies he took special delight and proved his allegiance to the ancient schools of philosophy by wondering what would become of things if their qualities were taken away.

Not every youth of nineteen has the good fortune to make discoveries in pathological work, but at this age Huxley described the microscopical anatomy of a layer of cells in the hair follicle which is still known as Huxley's layer and is described in erery modern text-book of Histology. While a student in Charing Cross Hospital medals were awarded him for excellence in Botany, Chemistry, Anatomy and Physiology. The University of London gave him the Mr.B. degree in 1845 , but as he was still too young to qualify at the College of Surgeons he began to cast about for something to do in the meantime, when lhe was advised to address the Director-General of the Navy for a position in Her Majesty's service. This was granted after due examination and Huxley began his first real work on board the "Rattlesnake" amid many hardships and privations, but reaping therefrom no end of valuable experience and contributing from his researches such important information regarding the flora and fauna of the deep sea that his papers were published in the transactions of 
the Royal Society. Later on, at the age of twenty-six, he was admitted as a member of that body and became a "Fellow of the Royal Society."

In 1858 there was published a "Review of the Cell Theory," * concerning which Sir Michael Foster (himself a most learned and entertaining writer on physiology) said: "A paper which more than one young physiologist at the time read with delight and which even to this day may be studied with no little profit. He (Huxley) drove the sword of rational inquiry through the heart of conception, metaphysical and transcendental, but dominant." Here one can see the breadth of Huxley's views and how he was able to project himself into the future with so remarkable a degree of accuracy. Not less noteworthy are his abilities as a compiler-he picked the best ont of everything and wove it into such a perfect organic whole that doubt concerning his correct. ness seems almost an impossibility. Another essay that brought its author no little credit in certain quarters was that "On the Theory of the Vertebrate Skull," a matter which the

The cell theory ennunciated by Schleiden and Schwann in 1838-39 instead simplifying our biological views has rather emphasized their complexity, especially in relation to evolution and inheritance. 
evolutionists had been quarreling about with more or less waste of words for some little time. Huxley, with characteristic energy, went to the foundation of things and demonstrated from the embryological researches of Rathke and others that skull and spinal column are independent of each other so far as development is concerned, and that the former is not a variation and adaptation of the latter brought about by the demands of the brain for a protective covering. This was a direct challenge to the teachings of Prof. Owen, the warmest supporter of axial deviation, and from that time on the good Superintendent of the British Museum considered Huxley his natural enemy.

Of this earlier work there is one characteristic that has been already referred to in a general way, and that is his eapacity for finding things out in books, or, as we commonly speak of it, book "research" as distinguished from that of laboratory. "Thoroughness in this respect was rendered easier by the fact that he read French as well as German with almost as much facility as his mother tongue."*

IIuxley especially desired not to be made conspicuous by his efforts to solve scientific problems. When Prof. Tyndall wished to name him joint author in the theory of glacial formation upon which both had been working, Hux-

* Life by his Son, Vol. I., p. 160. 
ley at first declined, and then, pressure being brought to bear, consented against his will. This fact is noteworthy considering the jealousies so often found among scientific investigators, and it is not reasonable to suppose that human nature then and now was at all different in this respect.

So far we have followed in a very hasty fashion the more important steps in Huxley's life from an infancy and childhood of more or less obscurity till we have found him rising rapidly to a place of authority among scientists of the nineteenth century; and, so far as external evidence goes, oblivious of his prowess and not at all spoiled by a knowledge of his intellectual superiority and the great good fortune attendant upon it. The next and major portion of this essay will have to do with his teachings as exemplified in the several lines of thought toward which his activities were directed. 


\title{
PART II.
}

\author{
HIS TEACHINGB.
}

I.

\section{Biological Teachings.}

ORIGIN OF THE UXIVERSE.

A primary requisite of any system of philosophy or religion worthy of recognition is the formation of some definite notion of the beginning of the world in the cosmos. At best this can be little more than a matter of speculation based upon such eridence as has thus far been furnished by the study of natural phenomena and their development into what we are pleased to call the physienl sciences. But the imperfection of such records as evidenced to us throngh the senses is at once manifest, and consequently these data admit of no end of varions interpretations, any one of which it is difficult to overthrow by mere abstract reasoning. Before the era of scientific inquiry Man was content to sit in darkness in reference to his relation 
to other objects in the universe; and if he thought about the matter at all it was to wonder or to admire, not to search or to study into the cause of the existence of things. For long years the explanation of the origin of the world lay deeply rooted in the soil of tradition, and so completely had human thought been imbued with ancestral beliefs that anything approaching a rational inquiry was deemed the rankest heresy, and was likely to be punished by a demand for the blood of the apostate. And this, too, not among the Medes or the Persians or the Babylonians or the Assyrians but even among the Pilgrim forefathers who first set foot on Plymouth Rock in the year 1620, A. D., establishing in the New World a reverence for the ancient order of things that in some ways has been of the most beneficial type; but which in others has bound down rational philosophic inquiry with the strongest of fetters.

Among advanced thinkers the Biblical interpretation of Creation has become no longer tenable, and even the most conservative have been obliged to admit its untrustworthiness. In the light of all the evidence poured in from every source this truth is little less than overwhelming in its unity however impotnnt it may be to aid in postulating new theories. Some have attempted to show that the story of Creation as given in Genesis is true, but that it has been wrongly interpreted, and that the six day limit 
should not be taken to represent twenty-four hour periods, but thousands or tens of thousands of years. This would do very well were it not true that the order in which animals are said to have appeared is also utterly confused and incorrect. For this we have to depend upon the records of geology, which are complete enough to build up a perfect order of events, and from which there has been no dissension in the geologieal camp, - a fact in itself of the greatest importanec in determining the accuracy of the deductions.

Concerning the existence of a First Cause there can be no reasonialle doubt. A finite mind must begin somewhere, and since spontaneity of origin is so contrary to all that we know of the working out of natural causes one is compelled to believe with IIuxley "That 'Creation' in the ordinary sense of the word is perfectly conceivable." Continuing he says, "I find no difficulty in conceiving that at some former period this universe was not in existence: and that it made its appearance in consequence of the rolition of some pre-existing Buing."

The past history of Nature is presented by Huxley in the form of three hrpotheses which seem to cover all the possibilities. I have endeavored to paraphrase them as follows:

1. The Lniverse has existed through all eter- 
nity in what may be broadly stated its present condition.

Whether true or false this postulate is not capable of proof by any evidence; for to prove it you must have either an eternity of witnesses or an infinity of circumstances, either of which is an impossibility. The testimonial evidence is inadequate because the antiquity of human records is relatively nil compared with the age of the earth, hence one is compelled to consider the circumstantial evidence alone. This circumstantial evidence is such as we can obtain only from a study of the earth's crust, which is composed of strata of sand, stone, clay, slate and numerous other materials. All of these we are constrained to believe are identical with those of the same type at present under formation everywhere about us through the influence of natural agencies. For example, the chalk of the hillside is found upon analysis to be one and the same with that brought up from the bottom of the Atlantic, and must have been formed in precisely the same manner as that which is now forming immediately under our eyes. Again, some fossils from archaic rocks are alike in all essentials to the animals and plants we see around us every day of our lives, which are being deposited in the mud of swamps and at the bottom of lakes just as they were deposited in bygone ages of untold length. As we dig deeper, however, into the strata we 
see morphological differences between animals and plants now existing and those of, say, the Pliocene or Eocene periods. This suggests that each species has had only a temporary duration and has diverged from the preceding and following species so radically that the doctrine of the identity of things terrestrial since their origin becomes a doubtful quantity. Pursued still further we can trace this evidence down through the lowest stratified rocks till we lose the indications of any kind of life altogether. Therefore the eternity hypothesis must be completely ruled out in so far as Organic Nature is concerned.

2. The present state of things has had only a limited duration; at some past period a condition of the world similar to its present condition came into existence and u'as not evolved out of a previous state. This may be spoken of as Milton's Hrpothesis, testimonial evidence for which is likewise unavailable, hence we must again rely on evidence of the circumstantial type. According to this hypothesis aquatic animals and birds appeared on the fifth day of the week of creation and no life existed before the fifth day. But life existed according to geologists in the carboniferous period in the form of insects of various type-spiders, scorpions, etc.-and aquatic animals and birds did not appear until the Jurassic period, therefore the Jurassic period must have preceded 
the carboniferous period, which is an absurdity. We have here a dilemma which may be stated thus: either the animals which came into existence on the fifth day were not like those which we find at present; were not the direct or immediate ancestors of those that now exist (in which case fresh creations or a process of evolution must have occurred of which nothing is said in the Bible); or else the whole story must be given up as hopeless.

3. The present state has had a limited duration, but has been evolved from some antecedent state and that from a pre-antecedent state and so on without limit so far as finite reasoning goes. For this view there are three kinds of evidence-a kind which neither helps nor hinders in establishing the facts of evolution and is therefore neutral evidence; a kind which indicates strong probability but which proves nothing and is therefore merely favorable evidence; and a third kind which is so convincing as to be fairly termed demonstrative evidence.

The neutral evidence would become negative evidence were it not for two facts: First, Darwin has shown that two chief factors are patent in the process of evolution-one of them is the tendency to vary, which may be well observed in all present living forms; the other is the influence of environment upon the parent form and the variations thus evolved from it. Secondly, the imperfection of the geological record 
which confuses almost as much as it assists in solving the problem.

There is a certain kind of evidence which favors the hypothesis that certain forms of life have persisted from their remotest origin almost unchanged. For example, we find that in the upper Niagara region there are remains of animals in perfect preservation, and among thein shells, belonging to exactly the same species as those now found at the bottom and on the shores of Lake Erie. According to Sir Charles Lyell's calculation these must be at least 30,000 years old, and they have not varied in structure or form for this relatively long period. The cretaceous epoch also shows forms which cannot be at all distinguished from present types, e.g., the Terebrantulae or lamp-shells; the Globigerinae or chalk-animals, whose skeletons make up a great portion of the English chalk, and which to-day live at the surface of all great oceans, being deposited at death upon the bottom and giving rise to a ehalky mud; and again the Beryx, a fish very closely allied to a species found at the present time in both the Atlantic and Pacific oceans.

These facts, however, scarcely argue against the theory of evolution, for we know that given certain variations from the parent type, the parent type may prove so much hardier in accommodating itself to environment that the offspring or variation finally dies out. Again 
the work of destructive agencies in nature, such as rains, winds, and frost have obliterated many evidences of former types and therefore have made the geological record imperfect; yet footprints of these former types may frequently be seen in the rocks, which do not conform to the footprints of any known species; hence we may be allowed to assume that they belonged to the obliterated variation derivatives. The doctrine of evolution is therefore not impaired by this line of reasoning.

The favorable evidence for the evolutionary hypothesis is derived from representation in animals of two types or forms, viz., the intercalary or intermediate, and the linear or immediate or direct. Cuvier was the first to show that paleontological research leads to the discovery of types of animals independent in themselves, yet serving to link together other types to which they bear some resemblance. The first of these was the Anoplotherium which proved to be allied to the pigs on the one hand, and to the ruminants on the other. Another was the Paleotherium which had characteristics belonging to the rhinoceros, the horse, and the tapir, creatures which to all appearances were entirely different and distinct. Thus gaps in our existing series of mammals have been and are being filled up more and more, strengthening the chain of phylogenetic progress.

Linear or direct types are best represented 
by the relation of birds to reptiles, at present so clearly distinguished from each other. So far as can be judged reptile life preceded bird life by a considerable geological interval, and the first birds were a compromise between creeping reptiles as we know them, and flying fowl which at present navigate the air. Professor Marsh of Yale first described two birds the Hesperornis and Ichthyornis, which differ from all existing birds in the fact that they possess teeth, thus placing them near the reptiles. Another remarkable skeleton is that of Archeopteryx, which has the foot and feathers of a bird, but possesses claws resembling in detail the termination of the fore limb of a reptile. Moreover it has a long tail composed of many vertebrae and fringed on each side with feathers. The limbs of certain reptiles and birds are very much alike, some reptiles being of the bipedal type. Others now extinct, properly classed as reptiles (the Pteryodactyles), were endowed with powers of flight.

The demonstrative evidence depends chiefly for its data on the structural development of the horse, and it is to America that the scientist turns to produce his proofs. In this work Professor Marsh of Yale received full credit from Professor Huxley. The succession of forms as now arranged carries us to the bottom of the Tertiary Strata. In receding order we have: first, the true horse, equus caballus; 
second, the Pliohippus or horse of the American Pliocene epoch; third, the Protohippus; fourth, the Miohippus, which corresponds quite closely to the European Anchitherium; and fifth, the Orohippus from the Eocene epoch, the oldest known member of the equine series. It is unnecessary to go into the osteological differences of these types, suffice it to say that they form a distinct and connected series from the four-toed Orohippus to the one-toed type which we in these days know as a very useful and trusted friend. "It has become evident," says Huxley, "that, so far as our present knowledge extends, the history of the horse-type is exactly and precisely that which could have been predicted from a knowledge of the principles of evolution. And the knowledge we now possess justifies us completely in the anticipation, that when the still lower Eocene deposits and those which belong to the Cretaceous epoch have yielded up their remains we shall finally come to the five-toed animals in which, if the doctrine of evolution is well founded, the whole series must have had its origin."

CONCERNING MR. DARWIN'S HYPOTHESIS.

One of Professor Huxley's characteristics was his honest desire for truth apart from any feelings of sentiment or friendship. In the light of this fact it became somewhat difficult 
for him to defend his position with respect to the hypothesis set up by Mr. Darwin; for it was well known how inseparable was the friendship between the two, and hence gossiping tongues had some excuse, perhaps, for discrediting Huxley's indorsement of the "Origin of Species" and the "Descent of Man." It was precisely this fact which led Huxley to declare that the last position in which he hoped to find himself was "That of an advocate for Mr. Darwin's views, if by an advocate is meant one whose business is to smooth over real difficulties and persuade where he cannot convince." In spite of the careful way in which they had been worked out Darwin's theories as first enmeiated were open to serere criticism and in this respect they were not ignored. Then as now jealousy was a rather too prevalent characteristic of human nature, and consequently many lost sight of the true goal toward which all were striving and became slaves to their own petty desires for everlasting fame. Huxley saw these faults, but he must have considered them unavoidable, for he says: "I adopt Mr. Darwin's hypothesis subject to the production of proof that physiological species may be produced by selective breeding just as the chemist adupts the atomic theory subject to the proof of the existence of atoms." But aside from all this "The whole analogy of natural operations furnishes so complete and 
crushing an argument against the intervention of any but secondary causes in the production of the phenomena of the Universe, that in view of the relations of Man to the rest of the living world I can see no excuse for doubting $\mathrm{Na}$ ture's great progression from formless to formed, from inorganic to organic, from blind force to conscious intellect and will."

It was necessary, however, to be perfectly fair and to give all dne credit to the propounder of the theory of the origin of species in spite of public opinion; therefore Huxley says: "I do not know of any proposition that has been put before us with the intention of explaining the phenomena of organic nature which has in its favor a thousandth part of the evidence which may be adduced in favor of Mr. Darwin's views. His work is the greatest contribution which has been made to biological science since the publication of the 'Regne Animal' of Cuvier and since the 'History of Development' of Von Baer. Stripped of its theoretical part, it still remains one of the greatest encyclopedias of biological doctrine that any one man ever brought forth."

Professor Huxley shows the true scientific spirit when he further declares that if, in the course of time, any good reasons are presented to his mind which declare that the hypothesis of evolution ought to be repudiated, he will 
hare no hesitation in pointing out at once any change of opinion.

\section{THE METHOD OF DISTRIBUTION.}

The distribution of animals and plants was a difficult thing to explain in connection with evolution, and although Mr. Darwin attempted it, his ideas on the subject were at the time scarcely acceptable. Huxley held that in a given epoch and a given area the Fauna and Flora can consist only of life that descended from the immediately preceding epoch. It is necessary to allow, however, for transformation of geographical features, in which case living forms from some other area might migrate into the given area and hence cause confusion as to similarity of biological form in different geological structures. There are two main hypotheses to be consilered, he thinks, in accounting for distribution of life: 1 . That distinct provinces of distribution have existed since the earliest date at which the life of any period is recorded, and possibly much earlier. 2. That progressive modification of terrestrial forms is more rapid in areas of elevation than in areas of depression; and that in the Permian epoch there was an upheaval of North America, Europe, Asia, and Africa, hence reptiles, hirds, and mammals rapidly spread into the new area from outlying prov- 
inces and formed the Triassic Arctogaeal province. Then followed a depression during the Triassic period with a checking of further development there, and a consequent progressive modification and development elsewhere. In the latter Mesozoic there was an upheaval around the shores of the Atlantic, and a movement of vertebrate Fauna westward increasing in extent up to and in some directions even after the Miocene epoch.

It is difficult to estimate the ralue of these, but relatively the second is worthy of the greater consideration and is borne out, in some particulars at least, by facts derived from various sources. A great deal of stress has been placed upon the synchronism of geological strata, but as Huxley well remarks, "All that geology can prove is that local order of succession, homotaxis (similarity of arrangement) and synchronism (identity of date) with regard to geological strata are not contemporaneous and prove nothing. The hypothesis of evolution explains the facts of Miocene, Pliocene, and recent distribution, and no other supposition even pretends to account for them."

\section{MAN'S PLACE IN NATURE.}

There is no longer any doubt as to the position man now occupies in the order of created things. Even the most radical unbelievers are 
one in the opinion that he represents the highest type of emlutionary development in thought, feeling, and will-in other words, that he holds his place as chief of the animal tribe because of his great mental enrlowments. In some respects he is quite inferior to many of the lower animals-he cannot soar like the lird, neither can he draw heavy loads like the ox; but by reason of his great brain power he has been able to overcome many of the physical forces of Nature and compel them to serve his needs.

For the establishment of "Man's Place," the whole world is indebted to the work of Huxley, who, in 1863, * "brought forward arguments of the linest scientific validity in support of the thesis that man is descended from animals, and that he is a mammal most nearly related to monkeys, and among these to the anthropoid apes."

It is just here that Professor Huxley gave evidence of his great ability and untiring zeal as an investigator; for it was necessary in securing data for the upholding of his arguments to venture into unexplored fields of anatomy and physiology, a task which he mdertook with the greatest boldness and carried through to the most perfect consummation. As a primary step he began with the study of the Nuandrithal Man and the Engis skull. These are the

* Metchnikoff. The Nature of Man. 
most complete remains that we have of the characteristics of our prehistoric prototype, and from careful asurements, the making of casts, etc., Huxley was able to estimate their anatomical relationship to the skeleton of man as now described, and to the skeleton of the anthropoid apes - gorilla, chimpanzee, and orang outang. As an aid in this work the reports of explorers of the Dark Continent and other unknown lands were carefully searched for descriptions of the animal types found there, and the best of these were taken subject to the laws of probability and coincidence and tested by all possible methods. The result of this laborious procedure, the details of which can be found in Huxley's book on Man's Place in Nature, was the enunciation of a categorical dictum that in every visible character man differs less from the higher apes, than these do from the lower members of the same order of Primates. Man is constructed on the same general type as other mammals, a fact which Darwin spoke of as "notorious" in its significance. Even the brain which is rightfully considered to be different because of its very apparent differences in function follows the same general law of development. Embryologically it is indeed impossible to distinguish in the early weeks between the developing ovum of a $\operatorname{dog}$ and that of man; but in the later stages the young human being presents marked 
differences from the young ape, while the latter departs as much from the $\mathrm{dog}$ in development as does the human type itself.

\section{PROGRESS OF BIOIOGICAI SCIENCE.}

Progress along all lines of human activity has become a truism and as such has been voiced so strongly and so repeatedly in recent years that to make mere mention of the fact is sufficient cause for enuui. Biological science has, however, escaped from such a fate and is being pursued with avidity not only in institutions of learning, but is of great interest to the general public. So patent has this fact become that some of the well-known publishers are bringing out popular editions of scientific works, a few of which have reached the hundred thousand mark in sales, thus rivaling in popularity the ephemeral modern novel.

Not every man of science is able to conserve the dignity of his subject when treating it in a manner designed for the edification of the general public-there are, though, a few such whose names are upon every tongue. Of these Tyndall, Huxley, Darwin, and Pasteur rightfully occupy the front rank. Concerning the latter it was Huxley's pleasure to speak in the most unequivocal language and certainly with entire justice: "The unremitting labors of that eminent Frenchman during the last 
half century have yielded rich harvests of new truths and are models of exact and refined research. Medicine, surgery, and hygiene have all been powerfully affected by M. Pasteur's work which has culminated in his method of treating hydrophobia. I cannot conceive that any completely instructed person can consider M. Pasteur's labors in this direction without arriving at the conclusions that, if any man has earned praise and honor of his fellows, he has."

\section{THE TEACIING OF BIOLOGY.}

Beyond doubt the efforts of such men, whose memory we delight to honor, have done more for the prevention and cure of disease and for the lengthening and saving of human life than simple mathematics can demonstrate. How very important, then, have become the problems of biological science as they relate to human welfare! How very important is a proper understanding of elementary physiology and hygiene! In establishing this fact and in maintaining it Huxley was a pioneer. He was constantly fighting for the introduction of proper methods of teaching these subjects in the schools of the United Kingdom, and, as for England herself, he was quite successful. Lectures, he thought, are indispensable because they awaken attention, excite enthusiasm, and 
offer a guide to the salient points of a subject. They explain difficulties and give a bird's eye view of the matter in hand. Demonstrations are important adjuncts because they educate the risual memory and furnish a picture from which hypotheses can be derived later on. But most valuable of all are examinations in studies pursued because they require a complete and accurate recollection of what has been learned. Knowledge of any biological study that is good for anything requires thought, discussion, and reconstruction, hence as a type of mental gymnastics scientific work of this kind is indispensable and can scarcely be replaced by other educational methods. One reason, then, why biology has progressed in popular interest is because it has been understood and because it is a basis for sound mental training. "Modern civilization," says Professor Huxley, "rests upon physical science; take away her gifts to our own country (England) and our position among the leading nations of the world is gone to-morrow; for it is physical science only that makes intelligence a moral energy stronger than brute force." 
II.

\section{Theological Teachings.}

It would be unwise to enter into a discussion of Professor Huxley's theological opinions partly because those opinions can scarcely be taken ex cathedra, partly because such a discussion would be inchoate and well-nigh useless. He belonged to a class of men who are scrupulously honest, not only with others but with themselves, and he was quite unwilling either to present or to accept an argument with nothing but faith to back it up-an attitude which belongs essentially to the mind of strictly scientific habits.

\section{SCIENCE AND RELIGION.}

For many years there have been two classes of thinkers in direct antagonism to each other: the one class who seek out every possible means of harmonizing the truths of science with revealed religion; the other who find nothing but discord between the facts of science and the elements of Christian faith. Concerning the 
latter Huxley says: "The antagonism between science and religion appears to me to he purely factitious, fabricated on the one hand by shortsighted religious people, and on the other by equally short-sighted scientific people." And in Science and Hebrew Tradition he ventures the opinion that, "The antagonism of science is not to religion but to the heathen surrivals and the bad philosophy under which religion herself is often well-nigh crushed." To the writer there seems to be no reason why the two are not interdependent, since religion has a true basis or foundation for its existence, and should need no support from science; and surely the position of science is so secure that she need have no feeling of jealousy or of disgust toward religious dogma or simple Christian faith. Wherefore then this controversy? Religion is not a thing capable of demonstration. It resides in the emotions and has for its fundamentals a firm trust in the ethical teachings of some system of philosophy, and a supreme belief in the concepts deduced from emotional religious experiences. If the Bible be true it should be true in its entirety, and hence does not need the support of scientifie facts or deductions; and if it be partly untrue it is not antagonized but stands openly convicted of falsity. What religion seems to need in these days is to be shorn of its creeds and doctrines and dogmas, and to get back upon 
a simple basis of the Judaic type. It should find place neither for discussion nor dissent. According to Huxley, "What we are usually pleased to call religion nowadays is for the most part Hellenized Judaism; and not infrequently the Hellenic element carries with it a mighty remnant of old-world paganism, and a great infusion of the worst and weakest products of Greek scientific speculation; while fragments of Persian and Babylonian, or rather Accadian mythology, burden the Judaic contribution to the common stock." This is surely a severe arraignment but is not entirely without reason; for such complexity cannot but result in a division into factions which undermine and weaken the entire fabric.

\section{RATIONAL BELIEFS.}

No belief is rational unless the senses have evidence of its soundness as founded upon external facts; yet it is indeed curious what a firm hold certain irrational beliefs takc upon the mind, and how difficult is their eradication. Everyone who has had any acquaintance with mental disorders knows how deeply rooted are the delusions and hallucinations of the insane. A lunatic will hear voices calling upon him to kill himself or plotting against him or his family, and so thoroughly grounded is his belief in the actuality of these external signs, that, 
unless carefully watched, he will probably obey these promptings and justify himself in their execution. It is not to be forgotten that what we call rational grounds for belief are often merely the desire to obey certain instincts which in themselves may be utterly irrational. These are frequently due to a faulty interpretation by the senses of the significance of percepts which are either incapable of correction or are allowed to go uncorrected. For example, a superstitious man while passing a graveyard on a dark night sees a white object which memory of something he has heard or read interprets to him as a ghost. Imagination runs riot, and, courage failing, he takes to his heels, feeling sure that he is pursued and can only outdistance the ghost by his superior flectness. The impression is uncorrected and he remains a believer in ghosts his life long, unless some one can induce him to investigate and prove to himself that his ghost was only a white gravestone. This is a familiar example of what anyone may experience, in lesser degree, perhaps, each day of his life, and when a false impression is incapable of correction it becomes deeply rooted in experience as a false but firm belief.

MIRACLES.

Right at this point it seems apropos to take 
up a consideration of miracles. "No conceivable event, however extraordinary, is impossible," says Huxley, "and therefore if by the term miracles we mean only 'extremely wonderful events,' there can be no just ground for denying the possibility of their occurrence." If a man tells me he has seen a ghost on Broadway I must admit its possibility while believing its utter improbability. Why do I disbelieve it? Because I myself have never had such an experience and insofar as I know no man whose reason and integrity have been unimpeachable has ever reported such an occurrence. Therefore I doubt until evidence is brought to bear upon the circumstance. If the man is a stranger I immediately test his sanity. If that seem to be undisturbed I then get from him all the details as to the exact time, place, surrounding conditions, etc., and if he cannot furnish these I tell him he was deceived. If he be a friend and I know his character I weigh all these things before passing judgment. Concerning the Biblical miracles Huxley affirms that "It is not impossible that the sun and moon should ever have been made to appear to stand still in the valley of Ajalon; or that the walls of a city should have fallen down at a trumpet blast; or that water was turned into wine." We must not call events impossible because they violate the laws of Nature as we understand them, but we should have sufficient 
evidence to show that our informant was not more than credulous, nor less than honest. We ought not to believe these narratives simply hecause they are found in Holy Writ, for there are to many possibilities of error aside from a simple desire to deceive.

\section{THEISM AXD ATHEISM.}

Reverence for belief in a Higher Power is a common attribute of mankind from the basest savage who worships the Sun to the highest orthodox churchman. It is inconceivable to finite minds that the Universe had no beginning and that it shall always continue as we know it. We know that it is under control of fixed laws, the harmony of which could scarcely be maintained without the intervention of intelligence; but when we seek to explain the origin of that intelligence we are absolutely powerless because we deal with the infinite and unknowable. The nice adjustment of details which the investigator of truth must find everywhere present in Nature compels admiration, while it also excites interest and a desire to study the more intimate relationships of material things. Since it is so necessary, then, to explain to oneself the characteristics of interrelated objects, as well as their origin and maintenance, it seems strange that a likely scientific hypothesis, and one which fulfils better 
than any other the requirements of facts, has been so often repudiated. The attitude of Huxley in this matter was non-committal; he found no proof that wonld appeal to a logical mind like his own concerning the nature of the Deity, and he just as certainly found none upon which to base a denial of that Deity's existence. He says: "Of all the senseless babble I have ever had occasion to read, the demonstrations of the philosophers who undertake to tell us all about the nature of God would be the worst, if they were not surpassed by the still greater absurdities of the philosophers who try to prove that there is no God."

It is necessary to recognize that there are a variety of facts in this world of ours concerning which we have not the slightest inkling; but if, in the absence of such knowledge, we find it necessary to our mental constitution to assume some theory about them, there is not the slightest harm in assuming that which seems to us most tenable in the light of cold reason; and, whether we be right or wrong, we have a point of reckoning from which to map out our course. In this attitude there is certainly an advantage. We can at least steal away carefully and cautiously along the shores of truth, leaving the hopeless derelict of doubt sailless and rudderless and without a port of entry on the ocean of total unbelief. 


\section{IMMORTALITY OF TIIE SOUL.}

For his lack of faith in this doctrine Huxley was severely scored by the clergy both in England and abroad. It was, however, perfectly natural to his frame of mind to disbelieve in whatever had merely an emotional basis. In a paper before the Metaphysical Society in 1S71, on "Has a Frog a Soul ?" he roiced the opinion that if St. Augustine, Calvin, and Jonathan Edwards have lield in substance the view that men are conscious automata, to hold this view with them should not brand a man a fatalist, a materialist, or an atheist. This scarcely seems relevant, however, for belief in conscious automata neither predicates nor denies anything concerning the life after death. That we are immortal because we are extremely desirous of being so to his mind contains the quintessence of suspiciousness, and since nothing ean be proved respecting the distinet existence, the substance, or the durability of the soul he does not think it a matter for disputation. "It is not a little strange that our strong desire that a certain occurrence should happen should be put forward as evidence that it will happen. If the mother's agonized prayer that her child should live has not prevented him from dying, experience certainly affords no presumption that the aspiration for immortality is any more likely to be 
gratified." Yet the immortality of man is not half so wonderful, he thinks, as the conservation of force or the indestructibility of matter. "Science warns me to be very careful how I adopt a view which jumps with my preconceptions. Science seems to me to teach in the highest and strongest manner the great truth which is embodied in the Christian conception of entire surrender to the will of God."

It will doubtless be difficult for many to reconcile these two statements, which seem rather hopelessly contradictory; but when one considers how the daily work of a man of science becomes his chief concern, his religion if you will, how it is bound up within him to the exclusion of almost everything else, one can see why the contradiction is only an apparent and not a real one. The tendency of modern thought along this and many other lines of religious dogma seems to be more and more away from the old traditional beliefs toward something more consistent with present day notions of natural phenomena. In this the scientific thought of the past quarter century has made a profound impression, whether for ultimate good or evil it is impossible to state. The fact is that as we begin to learn a little nore concerning rational causes of material operations we become impatient and are in danger of overriding the mark and landing in the slough of the unknowable. Many 
preconceived notions will doubtless have to be changed, but that change must be gradual, as the facts upon which those notions are based are gradually arrived at. In these days of apostacy it sometimes lnoks as though nothing short of a revelation will satisfy men of the truth or untruth of the fundamentals upon which Christian belief is based. The probable lack of such an occurrence gives little hope for the future welfare of a homogeneous and world-embracing faith, so that we may reasonably expect dissensions and the springing up of new ereeds throughout Christendom so long as the desire of men to know the truth concerning a future state exceeds their power of finding out anything certain either of its existence or probable character. As to this spirit of unrest, Iuxley saw in perspective what its outcome is likely to be when he said: "Modern thought is making a fresh start from the base whence Indian and Greek philosophy set out; and, the human mind being very much what it was six-and-twenty centuries ago, there is no ground for wonder if it presents indications of a tendency to more along the old lines with the same results." 


\section{III.}

\section{Educational Teachings.}

\section{A LIBERAL EDUCATION.}

The question as to what constitutes a liberal education is one for definition rather than for debate. When is a man liberally educated? Does it imply a college training, and does lack of college training debar one from coming under the "liberal" designation? These and perhaps other questions should be answered satisfactorily before setting out to describe what does and what does not belong under the classification. The term liberal means, of course, broad in the sense that its possessor must know something of the chief branches of general learning. He must have read history, studied literature, discussed politics intelligently, read of and seen examples of the chief masterpieces in painting and sculpture, and finally must be a man of the world interested in all things concerning the welfare of the commonwealth as well as those concerning the development of his powers of mind and body. This 
secins indeed a task so great as to bar out nearly every one from the distinction which its completion would offer; but, however difficult, two factors only are indispensable: the man and the opportunity. Of these by far the more important is the man; for with a fair degree of health and suitable conditions of life he can, by his own effort, force the opportunity and carry forward his work. He who complains that he never had a cliance to obtain an education deserves little sympathy. It is not the chance that he lacked but the inspiration and the energy, provided he liad merely himself to think of and not the needs of a family. Hear the words of Huxley on this subject, than which I do not think a better definition of a liberal education exists: "That man, I think, has had a liberal education who has been so trained in youth that his body is the ready servant of his will and does with ease and pleasure all the work that as a mechanism it is capable of; whose intellect is a clear, cold logic engine with all its parts of equal strength and in smooth working order; ready like a steam engine to be turned to any kind of work and spin the gossamers as well as forge the anchors of the mind; whose mind is stored with knowledge of the great and fundaniental truths of Nature and of the laws of her operations; who has learned to love all beauty, whether of nature or of art, to late all vileness, and to 
respect others as himself." Such a text should prove far-reaching enough for the most ambitious, yet it is scarcely unattainable even for those born under the most adverse conditions. The mind has no limit in the attainment of things knowable save its disruption from illuse, which is much less likely than disruption from ill-use of the physical being.

But the securing of a liberal education need not be entirely confined to men. In a letter to Sir Charles Lyell, Huxley declares that it is far from him to place any obstacle in the way of women who by endowment and energy are capable of making good use of their education in the world of ideas. He gave to his daughters the same training in physical sciences as their brothers received, with the expressed hope that other people would do likewise; and in this way the next generation would find women fit to be the companions of men in all their pursuits. "But," he adds, "I don't think men have anything to fear from their competition."

The higher education of women has become a fixed thing in this country, and some very excellent work in science, literature, and pedagogics, for example, has been done by them. Just how far this shonld be carried is in open dispute, for there are those who would set limits to the extent to which women should invade professional and commercial fields. There is 
an argument which is not devoid of merit to tho effect that hyher education tends to lead them away from motherhood and love of family associations. This is true, but to a limited extent. There are persons of both sexes who are fitted neither by nature nor by inclination for the matrimonial state, and who, since they are not hindered by the effects of passing emotions, can devote all their energies to the practical affairs of life with the single eye and strong laand of natural adaptability. Liberal education represents a potentiality of good, which, properly directed, becomes a great force for carrying the world's work onward and upward to a higher and still higher level of perfection.

PREPARATORY AND SUPPLEMENTARY EDUCATION.

In a strict sense of the term all education is preparatory, because it must fit the individual to better carry on his chosen work. But as Huxley consilered it there is a preparatory education for those who must go directly into the business of earning a living, and another kind for those whon can afford to take first a university traiuing. He believed that everyone should acquire as large a stock of general knowledge as he can possibly find time for; but the necessity that one shonld earn an immediate living takes precedence over all other consid- 
erations, and, hence, demands at all times the best that educators can devise in the way of practical instruction. There is, however, a supplementary type for this latter class of pupils, represented in our day by the University Extension morement, upon which Professor Huxley spent a great deal of precious time. $\mathrm{He}$ believed that the common people should be taught something concerning the things with which they come in daily contact, and that their powers of observations should be awakened concerning the vital forces of Nature. Accordingly he undertook to give instruction by means of lectures to intelligent workmen in Jermyn Street, London, and to his own and everyone's surprise soon found that these were exceedingly popular. The aim was to make his hearers familiar with the simpler aspects of scientific subjects. 'In doing this he would choose some very common subject, a horse, a piece of chalk, etc., and trace its growth and development in so logical and simple a manner that even a child could understand. These lectures were subsequently bound up together and published under the title "Physiography," and they exist to-day as the plainest and most interesting exposition of natural phenomena in the English language.

UNIVERSTIES: ACTUAL AND IDEAL.

The actual and the ideal in miversity train- 
ing are by no means interchangeable terms. The ideal unversity exists chiefly in the imaginations of educational reformers, or in the minds of those who do not at all favor present methods of instruction in any of their details. There is, however, according to Huxley, an ideal university which is a simple modification of what we now have, and which be characterizes as follows: "In an ideal university, as I conceive it, a man should be able to obtain instruction in all forms of knowlerge, and discipline in the use of all the methods by which knowledge is obtained. In such a University the force of living example should fire the student with a noble ambition to emulate the learning of learned men, and to follow in the footsteps of the explorers of new fields. The very air he breathes shonld be charged with that enthusiasm for truth, that fanaticism of veracity which is a greater possession than much learning; for veracity is the heart of morality." Such an institution would classify the forms of knowledge somewhat after this fashion:

1. Knowledge of man's mental faculties as derived from a study of Logic and Psychology.

2. Knowledge of man's welfare as derived from a study of Sociology and the teachings of Moral and Religions Philosophy.

3. Knowledge of phenomena of the Universe as derived from the physical sciences, Astronomy, Chemistry, Physics, etc. 
The list of studies in the curriculum would be shortened instead of lengthened, and the aim would be to gain thorough and sound knowledge of each, rather than an indefinite smattering of many. In Astronomy, for instance, the student would be taught to point out the chief planets and their relations as to magnitude, distance, etc., rather than to define "parallax" or the "precession of the equinoxes." The highest function and constant effort of such a University would be to seek out those men who are able to carry the interpretation of Nature a step further than their predecessors, and then to grant them every possible opportunity in attaining this end.

The actual University is hampered somewhat by the inefficiency of many of its students. "Students come to the Universities ill-prepared in classics and mathematics, not at all prepared in anything else; and half their time is spent in learning that which they ought to have known when they came." This condition is quite as common in America as in "The Three Kingdoms," but it is one which should be easily remedied by increasing the entrance requirements in those subjects where the greatest lack is manifest.

Huxley thought that original investigators should devote a moderate portion of time to lecturing or to superintending practical instruction-it is a decided advantage not only 
to the student but to the investigator himself; for there is no better way to the thorough understanding of a subject than the effort to explain it to others in language easy of comprehension. $\mathrm{He}$ did not think much of the methods of examination now in use because they "tend to detoriate students by giving them a false idea of the purposes and uses of knowledge." "Students work to pass, not to know. I believe that examinations will re-main but an imperfect test of knowledge, and a still more imperfect test of eapacity, whilethey tell next to nothing about a man's power as an investigator." But, we may ask with reason, Is the sole purpose of education to make every man an investigator? Most assuredly not, for few there be who have the necessary qualifications for work of so exacting a nature, and most of us have to be content with the remoulding of other people's ideas. As a mental exercise I do not think examinations can be excelled. They should, however, be frequent enough to cover an entire subject and throw light upon it from every possible source. It is of little use to sit down and commit a lecture or a text-book to memory. It is not memory but reason that neerls to be cultirated, and the student who insists upon getting a satisfactory answer to his "Whys?" will stand nearest the head of the class because he knows the relation between cause and effect in 
so far as such relation is demonstrable. Then, too, examinations do little or no good if false or incorrect statements are not subsequently corrected. The method of grading papers and throwing them away is most reprehensible and cannot be too strongly condemned. Grades or percentages indicate in an imperfect way the degree by which one student's understanding of a subject exceeds that of another, but they do not explain any mistakes and do not educate.

\section{SCIENCE AND CULTURE.}

Is it possible to be cultured without a training in the classies? That is a question which of late years has been open to no end of discussion, and is by no means settled. Huxley thinks that the majority of educated Englishmen hold that the man who has learned Latin and Greek, however little, is educated-a statement which is absolutely devoid of sense so far as the Englishmen are concerned. I hold that culture in its essentials is an inborn trait, and that it is just as impossible for some men to profit by cultural studies as it is impossible for the lower order of animals to profit by them. Matthew Arnold tells us that culture means "to know the best that has been said and thought in the world," but he would have come nearer the truth if he had said to know and to do the best that has been thought and 
said in the world. Classical studies teach that which is, not that which ought to be. It is perfectly possible for a man to run the entire gamut of Greek and Latin and Hebrew and Persian and a score of other tongues, ancient and modern, and still be the veriest boor in thought, speech, and deed. It is also possible for a man to know intimately none of these things, yet to evidence his love of the humanities in a thousand other ways that bespeak refinement and culture in every gesture.

Professor Huxley holds very strongly by two opinions: "The first is that neither the discipline nor the subject-matter of classical education is of such direct value to the student of physical science as to justify the expenditure of valuable time upon either; and the second is, that for the purpose of attaining real culture, an exclusively scientific education is at least as effectual as an exclusively literary education."

The classics are undoubtelly desirable, and especially so to the appreciative; but to the unappreciative and essentially practical mind they are a waste of time. Literature is beyond doubt the basis of culture, for it contains the finest products of the finest minds. It is, however, so accessible in these days that no one need of necessity be illiterate; and certainly if culture does not depend upon a knowledge of the grammar of unfamiliar languages, some- 
thing can be gained from a study of the many good translations which may be had almost for the asking.

"For those who mean to make science their serious occupation," says Professor Huxley, "or who intend to follow the profession of medicine; or who have to enter early upon the business of life; for all these, in my opinion, classical education is a mistake." And again: "I find myself wholly unable to admit that either nations or individuals will really advance, if their common outfit draws nothing from the stores of physical science." But, he does not think such training should be exclusive, for it will bring about a mental twist just as surely as will an exclusively literary training.

\section{TECHNICAL EDUCATION.}

Great stress is laid by Huxley upon the value of technical education, because survival means to turn out a superior product than your neighbor can do at a relatively cheaper rate, and only brains can supply this need. This has been beyond doubt a very important factor in the development of American commercial interests; for it has been the effort of our chemists and inventors and manufacturers to produce the best article possible at the least possible costa spirit which has pervaded our industrial pursuits throughout the United States. 
But he speaks more particularly of medical education as the basis of recent advances in medicine and surgery. He believes in the study of strictly medical subjects. Let the druggist learn all the finer points in materia medica and botany, the physician merely wants to know when and how to use the essentials. "Any man who has seriously studied all the essential branches of medical knowledge; who has the needful acquaintance with the elements of physical science; who has been brought by medical jurisprudence into contact with law; whose study of insanity has taken him into the fields of psychology, has ipso facto received a liberal education."

The value of special education in its influence upon the well-being of the commonwealth is no insignificant or inconsiderable affair. There is always the danger, however, of reducing the finer sense of things to nothingness in favor of the practical and seemingly more essential. This is not so of necessity, and the technician who gives up everything for his special work will soon find his life blighted and out of harmony with the beauty that lies vrerywhere about him in the wonderful complexity of Nature. 
IV.

Moral Teachings.

THE BASIS OF MORAIITY.

The moral sense has as a fundamental element the consciousness of distinction between right and wrong. On the judgment as to the relativity of right and wrong depends the fibre of the social fabric and the laws which govern the actions of men. There is a commonality of opinion which decides that an action is wrong partly because education and experience have shown its untoward results, partly because they have shown favorable results from the opposite course. Moral reasoning is a very complex type of mental reasoning. dependent in part upon a knowledge of pleasure and pain, approbation and disapprobation, which has been gained from individual experiences since birth. The untaught child has neither the sense of honor nor shame, becanse it is wholly unconscious of self, and of the influence of its actions upon those about it. Just so soon as it becomes conscious of this relationship it ceases the per- 
formance of certain acts altogether, or indulges itself only when in private. There is therefore an innate sense for the judgment of conscious acts which responds to the evidences of experience, highly developer in certain individuals and almost wholly lacking in others. As this latter type fortunately represents a very minor portion of mankind, those who deviate from the former standard are recognized by students of abnormal psrchology as moral degenerates and are classified among the irresponsible or insane. The conditions may be congenital, in which it most often takes the form of kleptomania or of sexual perversion, or it may be acquired through disease, taking any form toward which the natural passions of the individual are inclined. This latter is most often seen in general paresis or, as it is otherwise known, paralytic dementia. Right conduct depends very largely on the inhibitory control of the higher cerebral centers, and consequently when this control is removed the individual becomes physically incapable of proper exercise of judgment. In the maniacal this becomes a matter of clinical experience; for it is a common observation that in mania (manic depressive insanity) persons often indulge in the most obscene and profane language, no matter how great their previous degree of refinement, culture, or religious predilection. 
As Professor Huxley conceives it, moral duty "consists in the observance of those rules of conduct which contribute to the welfare of society, and by implication, of the individuals who compose it." He defines character as "The sum of tendencies to act in a certain way," and adds that it is often to be traced through a long series of progenitors and collaterals. He does not think it a matter of religious inclination primarily, for it can exist independently of any belief in church doctrine, although it is often strengthened and fortified by close adherence to the commonly observed tenets of Christian faith. It is not a matter of emotion, but is based on sound principles of truth, and an appreciation and love for what is conceded to be the best in the dealings of man with man.

\section{PESSIMISM AND ALTRUISM.}

It is impossible for a belief that everything in the world is going to the bad, and a hope for deliverance in order that the entire race may thereby be benefited to exist in the human breast at the same time. The pessimist is at best an unwholesome, self-centered and morbid individual whose narrow views and hopeless outlook are a very reflection of the worst element in mankind. He may not commit murder, but he is scarcely too good for it; for what 
need is there that any one should live in such a hotbed of iniquity as constantly presents itself before his myopic vision. He professes only a love for others, while thinking entirely of himself; and as to the real causes, effects and ultimate results of this or that action he is as utterly bewildered as a lost babe in a London fog.

The altrinist is also an extremist, but he errs on the better side. $\mathrm{He}$ does not believe that the struggle for existence is a natural ontcome of uncontrollable physical forces; but if he did he would only wish for their annihilation and for a reconstruction of "this sorry scheme" to something more akin to the heart's desire. Strife is for him a sad, sad thought, and in his ideal world he would see only perfect harmony, and orderly sequence in human relations. His sphere would be characterized by a sort of undiluted politeness, by which each person would court self-extermination in order to bring about the greatest good to the greatest number. Huxley was neither a pessimist nor an altruist. I do not know that he would have liked the name of optimist or even that of meliorist; yet he was always full of hope for the future whatever it might hold in store. He beliered that "The world is neither so good nor so bad as it conceivably night be; and as most of us have reason now and again to discover that it can be." $\mathrm{He}$ was a moralist without being a senti- 
mentalist, he studied to find ont the best, yet did not allow himself to force his convictions upon those who could not receive them with open mind.

THE QUESTION OF VIVISECTION.

Among a certain set of people the use of animals for experimental purposes will always be looked upon with horror. In these days one does not hear so much against the practice of vivisection as formerly, because the public has come to understand the tremendous advantages science has obtained through analogy in the study of disease and of the application of these ideas to the saving of human life; but in Huxley's time the war waged fiercely between the philozoics and the philosophers. Quite naturally Huxley took the argument for the scientific side, although by nature he was an animal lover. But it was very easy to show how shallow was the reasoning which did not cry out against paining animals for sport or food, vet tried in every way to prevent their use in carrying forward biological investigation. He showed how greatly prohibition would hamper the progress of medicine and surgery and declared that "Not a single one of the great truths of modern physiology has been established otherwise than by experiment on living 
things. . . . I ask myself-suppose you know that by inflicting pain on 100 rabbits you could discover a way to the extirpation of leprosy or consumption or locomotor ataxia among human beings, dare your refuse to inflict that pain? I am quite mable to say that I dare."

With the use of anesthesia many of the objections to vivisection even among scientific men themselves gave way, for it is now possible to conduct such experiments as any ordinary surgical procedure would be carried out-entirely without the knowledge of the patient. Huxley considered quite rightly, "That wanton infliction of pain on man or beast is a crime, the pity is that so many of those who (as I think rightly) hold this view seem to forget that the criminality lies in the wantonness and not in the act of inflicting pain per se." He foresaw that unless the fanaticism of the humanizers overpowered the voice of philanthropy, and lore of domestic animals superseded the love of one's neighbors, experimental biology would, in course of time, place preventive medicine as well as practical therapeutics upon a high plane of usefulness. This forecast has certainly been verified by subsequent developments; but even now the things that have been done are as nothing to those that will be done within the next twenty years. Even questions of right and wrong have their 


\section{Teaomings of Thomas Huxley}

limitations, and, as the world moves on, old ideas of whatever sort must give way before what we are pleased to call advancing civilization, if that civilization is to be of the highest possible type. 


\section{v.}

\section{Teachings Concerning the Gospel of Work.}

PURPOSES IN HUXLEY'S LIFE.

In a life so full of arduous effort it is interesting to know the source which prompted it to constant and continued action. Was it ambition? Desire for fame? Selfish vanity? Unappeasable energy? Philanthropy? These questions and many more may be asked with perfect reason when a great man has passed away; and in Huxley's case it would be difficult to find a suitable answer were it not that he has explained it all so simply in his brief autobiography: "If I may speak of the objects I have had most definitely in view since I began the ascent of my hillock they are briefly these: To promote the increase of natural knowledge and to forward the application of scientific methods of investigation to all the problems of life to the best of my ability; in the conviction which has grown with my growth and strengthened with my strength, that there is no alleviation for the sufferings of mankind 
except veracity of thought and action; and the resolute facing of the world as it is when the garment of make-believe by which pious hands have hidden its uglier features is stripped off." Not a very full creed, one might say, yet it embodies a whole world of ideas, a lifetime of sacrifice for and devotion to duty, an eternity. of impossibilities in solving the unknowable.

\section{FAITH WITHOUT WORKS.}

There are those among men whose chief pleasures lie in the fragile and foundationless edifices of the imagination. Who indulge in stuporous thought by day, and are beset by ominous and wonderful dreams by night concerning what they might have been or may yet become if conditions were only different. They neglect the tangible and real of the everfleeting present for some fetish of the irrevocable past or uncertain future. They fail to see that the two things needful for success, and eren these sometimes fail, are wholesome, deliberate thought concerning the things nearest at hand, followed up by spontaneous, concentrated action. Thought and action are the inseparable elements which form the keystone of the arch through which men pass to success. If the thought or the action or both be of an improper nature or are ill-timed the result is 
failure. It is one of Nature's constant laws. It cannot be evaded.

In the darker days of history, and that, too, not so very long ago, certain men deeply imbued with the spirit of religious faith, ignorant of natural causes, and heeding not in their frenzy the Biblical mandate of "faith without works"-even in those days certain men and their families were swept from the face of the earth through pestilence or through famine while supplicating the sky for deliverance. They knew not what to do so they did nothing and suffered the penalty. These were the times in which the wrath of God was visited upon the people for their iniquities. It was Egypt sore stricken with the plague. It was Babylon delivered into the hands of the enemy. It was Nineveh consumed by fire. The prayers of the High Priests and of the hosts were likewise unarailing. Since that time, says Huxley, we have learned that "Pestilences will only take up their abode among those who have prepared unswept and ungarnished residences for them. Their cities must have narrow, unwatered streets foul with accumulated garbage. Their houses must be ill-drained, ill-lighted, ill-ventilated. Their subjects must be illwashed, ill-fed, ill-clothed."

There is very little to be gotten out of life unless one chooses to put a great deal into it; and the relation between the quantity. of seed 
sown and the fulness of the harvest must ever be direct and immediate. The age is long since passed when the walls of Jericho will tumble down through the faith of the many. If they do so without the aid of a modern weapon of war we shall find the phenomenon explainable upon very natural causes, and the time at which they fall as the barest coincidence.

\section{EFFORT A LAW OF LIFE.}

It should not be that the chief end of man is to spare himself from the toil and care that make life such a tremendous responsibility. He is by birth a servant and not a Master or King. His chief duty lies in obedience to the mandates of conscience and to the needs of the world. Says Huxley: "We should cast aside the notion that escape from pain and sorrow is the proper object of life. We are grown men and must play the man bearing the evil in and around us with stout hearts set on diminishing it." Is this not sufficient answer to the question, Is life worth living? To my mind no one but a coward can have any doubt about it. As long as we are in the world, we must be of the world, doing our stint of work as well as we can, no matter how small that stint may be, or how ineffectual our efforts may prove. Much of the best work now being accomplished is being done by the great masses 
of "the common people" who hold no claim to greatness or goodness other than the right to use the labor of their hands in securing a livelihood. The mutual dependence of man upon man cannot be ignored, it has held good throughout the everlasting ages, in the hut of the savage as well as in the palace of the millionaire.

Some have thought that the great advances of civilization toward a higher plane of living is ominous of the near advent of the millenium. It has been sufficient reason for leaving the plow standing mid furrow, and for taking up the pen to write learned disquisitions on life after death, or the probable nature of our future state. I see no reason for supposing that the end of the world is near at hand or that we have gone as far as we can go in the process of perfection. I do not know that it is to have an end, and I am equally ignorant as to what is meant by perfection, and as to whether that state is a factor in the matter at all. We know of stages of transition, for the evidence that changes have taken place lies everywhere about us. We do not, however, know anything about catastrophism, and it is certainly a very fortunate thing for our peace of mind that we don't. Even the theory of evolution encourages no millenial anticipations, says Huxley. Of course, "If for millions of years our globe has taken the upward road, yet, some time, the 
summit will be reached and the downward route will be commenced. But I see no limit to the extent to which intelligence and will, guided by sound principles of investigation and organized in common effort, may modify the conditions of existence for a period longer than that now covered by history." There is, therefore, reason enough for a broad and unselfish view which depends upon industry and thrift for the chief pleasures of its existence, upon a knowledge of the harmony of things in the universe and of its constituency in making that harmony of a purer and diviner sort. 
VI.

Teachings Concerning Individual Rights.

NATURAL AND POLITICAL RIGHTS.

All living things are endowed with certain natural rights peculiar to themselves but shared to a greater or less extent by kindred species. They have the right to live, thrive, grow, form themselves into colonies, beget new species, and to pursue and kill their prey. These rights are truly of the inalienable sort because they are the expressions of general processes in Nature. The anatomy of beasts of prey shows a morphology well adapted to the slaying and tearing to pieces of the animals upon which they feed. For instance, the tiger is possessed of sharp claws, powerful muscles, large jaws, strong teeth and a certain native quickness and alertness. It has a right, therefore, to carry on a sort of internecine warfare because of the structure of its body, the necessity for survival and the hereditary instinct of its kind. Moreover it has the same right to eat man as it has to eat other animals. But man maiking use 
of his natural mental endowments, has the right to defend and protect himself against the tiger by inventing guns, knives, snares, etc., and the right to use them as occasion demands. In this sense right is almost synonymous with ability. Animals of the same species seem to appreciate a sort of equality, even though recognizing the struggle for existence, and hence find it more advantageous to band themselves together than to keep up a constant struggle for supremacy by fighting each other. With the higher types comes a still further analysis of this condition, until in man one finds wilful murder good and sufficient cause for the death of the murderer by the hand of the law, which represents nothing more than authoritative opinion of the majority. The relationship of man to the other animals is one of degree, and he has only been able to place himself at the head of the sentient world because of his great success in the struggle for existence. This he has done by seizing everything and holding it tenaciously, and also by gentler qualities such as cunning, sociability, curiosity, and imitativeness.

Man's political rights are artificial in origin, and have been worked out by those of his fellows who have a fondness for controlling and governing. It has been found that peace and order cannot be maintained in human society without the setting up and close observance of 
a code of rules which shall apply equally to all of its members, and these are bases of all laws. 'This means the limitation of the freedom of the individual when that freedom interferes with the peace of mind or spontaneity of action of his neighbor. Theoretically there have been certain statements put forth to show to what extent a man has the right to make use of his powers to further his own ends. It is just this principle that has brought up no end of discussion in the United States regarding the legality of the Trusts. Is it or is it not right that men should be privileged to band themselves together to monopolize certain products which may be largely such as were secured by their own efforts? Huxley thinks it impossible to establish any proof that such action is eitber. a natural or a political right and in this he directly opposes the principles of Henry George as that author set them forth in his "Progress and Poverty." The view is coming to be generally held that no man has the right to set up a system which in any way makes it impossible for another man to secure his living. By so doing the struggle for existence becomes a wholly limited and one-sided affair, since it does not give an opportunity to the less fortunate individual to use such powers as he possesses to compete for the necessaries of life. 


\section{COMMON OBLIGATIONS.}

There are certain obligations which are essential to social existence. That all men are created free and equal as it is commonly understood is the basest sophistry; but that all men are endowed with certain inalienable rights, among which are the right to life, health, and the pursuit of happiness, is crystallized wisdom of the purest sort. The support of this principle becomes, therefore, a primary obligation upon each member of society if that society is to be permanent and of the best possible type. "Society is impossible," says Huxley, "unless those who are associated agree to observe certain rules of conduct towards one another; its stability depends on the steadiness with which they abide by that agreement." Political reasoning of the a priori order is not only faulty but may lead to serious difficulty. Experience is sometimes fallacious; yet it is the chief guide to the solution of all important matters of State, and those who discuss political and social questions from the professorial chair are little less than dangerous if their ideas are not largely moulded and colored by sound experience in the world of politics. The greatest statesmen have never been very profound writers on speculative subjects, for they have found themselves too completely, occupied with 
actual problems to enter the field of the ideal. On them has devolved the obligation of knowing the teachings of experience.

To know the right and to uphold it is the prerogative of the educated man as it is the duty of the uneducated. Obedience to a common principle depends upon the individual. As Huxley well said, "The higher the state of civili. zation the more completely do the actions of one member of the social body influence all the rest, and the less possible is it for any one man to do a wrong thing without interfering more or less with the freedom of his fellow citizens."

IXCESSIVE PROCREATION AND THE STRUGGLE FOR EXISTENCE.

The Malthusian doctrine that as population multiplies the means of subsistence grow less is a perfectly obvious fact. Malthus' belief, however, that a time must come when population would so far exceed subsistence that great numbers of the poorer classes would starve to death has scarcely been realized. For present purposes one may consider, in this country at least, that the supply of things needful for the maintenance of human life is well-nigh inexhaustible; and that, when people starve, evidence is given not of a fault in quantity of food, but a fault in the distribution of food. 
Starvation implies either a lack of initiative, or physical incapacity to earn a living. We have still vast areas of tillable and fruitful soil which may be had almost for the effort of settling upon them, but which are still lying idle because the poor in our great cities either do not know of the opportunity or are loath to leave city life in spite of its squalor. The physically incapable must, of course, in many instances become the recipients of charity. So long as philanthropy exists they are in less danger of starvation than any other class.

We see, therefore, that the struggle for existence is a very useful means of accomplishing a very useful end; for were it not absolutely imperative that man earn his bread by the sweat of his brow human progress would cease, and the fabric of civilization would decay until the barbaric state were again arrived at. Says Huxley: "So long as natural man increases and multiplies without restraint, so long will peace and industry not only permit, but they will necessitate, a struggle for existence as sharp as any that ever went on under the régime of war." So far as excessive procreation is concerned one need have no fear but that disease and death will adjust population quite in accordance with the means of subsistence. Among the poor they have been, and doubtless always will be, the chief means of bringing about such an adjustment. 
CARITAL AND LABOR.

In an address on "Capital-the Mother of Labor," Huxley made plain the lack of antagonism which should exist between these two because of their mutual dependence. "Of all political delusions which are current in this queer world the very stupidest are those which assume that labor and capital are necessarily antagonistic; that all capital is produced by labor and therefore by natural right is the property of the laborer; that the possessor of capital is a robber who preys on the workman and appropriates to himself that which he has no share in producing. . . . Capital and labor are close allies; capital is never a product of human labor alone, it is the necessary antecedent of labor, and it furnishes the materials on which labor is employed. There is no intrinsic relation between the amount of labor bestowed on an article and its value in exchange."

This is the very essence of truth in any discussion on the relation between capital which makes the establishing of a business possible, and labor which simply makes the establish. ment capable of production. The workingman's argument that he ought to receive more wages because his employer is making more money is the basest sophistry. His work is 
worth only a certain fixed sum, and any excess over this in wages should be considered by him as a gratuity. He does not earn more unless he enables his employer to turn out a better, more highly finished product as the result of his independent efforts. As a matter of justice capital should see to it, however, that labor is rewarded by a sum sufficient to keep it at a high level of perfection in the securing of food, clothing, and habitat.

\section{ESSENTIALS OF INDUSTRIAL DEVELOPMENT.}

The question as to how employers should teach employes the proper expenditure of their wages is an ethical rather than an economical one. It is, though, very important as influencing the satisfaction or dissatisfaction of the laborer with his condition. Huxley thought it very important that the workingman be taught how to live. "To improve the condition under which our industrial population lives, to amend the drainage of densely peopled streets, to provide baths, to facilitate habits of thrift, to furnish some provisions for instruction and amusement in public libraries and the like is not only desirable but an essential condition of safe industrial development." The laborer does not need education so much as he needs enlightenment concerning the conditions necessary to bealth and prosperity. Education sometimes 
has an unhappy result in establishing for him ideals of wealth or social condition to which he cannot attain; and consequently these make him very unhappy. What is indispensable for him is to know the significance of germs as the cause of disease, how they are propagated in damp, dark, and filthy places, and killed by dryness, sunlight, and scrupulous cleanliness; how personal cleanliness is conducive to health; how exercise, proper food, and sufficient sleep safeguard the body from disease and premature decay; and how improper moral living may bring ruin upon his wife and family and descend upon posterity. Of general education he may know nothing other than the ability to read and write, and he will be happy in virtue of rather than in spite of his deficiency. These are the individual rights of the common people; to deprive them from obtaining these rights would be a crime; to teach by precept and example is the work not of the city missionaries alone, but of all good citizens who can give time or money to bettering municipal and national life. 
VII.

\section{Psychological Teachings.}

DEVELOPMENT OF THE MIND.

The higher one goes in the animal scale the more he is impressed by the weakness and helplessness of the offspring at birth. In the lower orders the young are born with most of the qualities which are to be of service to them throughout life in satisfying their bodies with nutrition. The calf, for instance, is born with all the teeth he will ever possess, and can skip and play within an hour from the time he leaves his mother's womb. All he needs is sunshine, air, ford, and a small spot of ground to lie down upon. The same is true of many other domestic antmals. With the human species, the exact reverse holds true. The new-born infant can do little more than cry and move his arms and logs, all things else must be done for him; he cannot even reach the breast without the aid of his nurse. The special senses ouve touch are exceedingly inactive, and it is doubted whether he can see, hear, taste, or smell 
until several hours or dass old. The higher functions, then, of thought, feeling, and will are quite embryonic in the human being at birth, and only develop after a relatively long period of education and experience. As Professor Huxley expresses it, "In the new-born infant the Ego is little more than a bundle of potentialities. But later on these become actualities, dulness or brightness, weakness or strength, viciousness or uprightness, with each feature modified by confluence with another."

If we imagine an infant born into the world on some desert island, without precept from its kind as to what it should or should not do, cared for as are the plants by the kindness of the soil, we can grant quite readily that it will grow up and become little more than a regetative mass. Thought would still be possible, but only such thought as animals possess in keeping themselves out of harm's way. Speech would, of course, be impossible and there would be little or no cause for comparing itself with the objects about it. Mental development, therefore, is scarcely possible without bodily activity, and bodly activity is largely imitative, certainly in so far as movements of precision are concerned. But given a child on a desert island who must shift for himself to satisfy the wants of his being, development of intell. gence to that degree would be quite rapid but would scarcely proceed beyond it. Natural 
knowledge Huxley thinks first began "When the reason of man first came face to face with the facts of Nature; when the savage first learned that the fingers of one hand are fewer than those of both; that it is shorter to cross a stream than to head it; that a stone stops where it is useless unless it be moved, and that it drops from the hand which lets it go; that plants and animals grow and die." All these things were forced upon the mind as a natural sequence of man's relation to those objects concerning his welfare. Reason, however, conld searcely be said to exist; for in such dealings with Nature there is no need to weigh facts one against another, the only requisites are observation and memory acting to preserve the savage from pain or death.

\section{MAN'S SUPERIORITY.}

In a general way this has been discussed in the section on Man's place in Nature, it only remains to be seen why man is superior to other animals. "What is it that constitutes and makes man what he is?" says Huxley. "What is it but his power of speech, of recording experience, and, in some dim sense, understanding the working of this wonderful universe? I say that this functional difference is vast, unfathomable, and truly infinite in its consequences; and I say at the same time, that it 
may depend upon structural differences which shall be absolutely inappreciable to us with our present means of investigation." He considers that without speech man would scarcely be entitled to lay claim to superiority; that if all men were suddenly struck dumb we would be but little removed from the brutes; and that the moral and intellectual differences might still be infinite, yet the naturalist should not be able to find a single shadow of specific structural difference.

This night be true in a strict sense, and would hold for men dumb; but so long as thought exists communication must go on between man and man in one form or another, and I believe we should soon accommodate ourselves to the new conditions. Even were this not so, if thought still existed there would be plenty of evidence in man's work to prove his superiority; therefore it does not seem that speech is primarily essential howerer indispensable. The real cause of man's superiority is because he has developed mentally and physically into something more than an automatom, and is capable of making his will predominate over other animals to the extent that he can control them through his ingenious contrivances.

INSTINCT AND REASON.

'As was mentioned abore in the section on 
Evolution, the anatomical structure of the brute brain is very similar to that of the human. Both the gross and microscopical appearance of the eye, ear, alfactory organs, nerves, and spinal cord in the ape, $\operatorname{dog}$, and man are almost identical; and experimentally each have been cut, punctured, and anesthetized with quite the same result. Huxley was inclined to the belief that animals possess a sort of mental power comparable to reason. He cites the fact that dogs, when sleeping, appear to dream, for they go through some of the motions during sleep that they are accustomed to perform when awake, such as brushing flies from the nose, wagging the tail, etc. If they do dream, he concludes, ideation must go on while they sleep, and consequently this must be but the reflected image of their true waking state. This seems to be stretching the point; for simple observation is altogether insufficient ground upon which to base such a far-reaching conclusion. The automatic and reflex functions of the spinal cord may and sometimes do deceive the observer; for there is no reason to suppose that the cord is at all endowed with the higher psychic functions, and one may confound such effects with those proceeding as the result of action in the higher cerebral centers. For example, the decapitated frog tries to stroke off an irritating acid from his back, and if the cephalic portion of his body were concealed it 
would be quite difficult for an observer to tell whether the effort were a conscious or a reflex one. Huxley also thinks that dogs have something akin to snobbishness, for they bark at beggars and do not bark at the well dressed! As a matter of common experience this evidence is searcely trustworthy, for they are known to do exactly the opposite in many instances.

The vagneness of the term "instinct" as commonly used may signify acts accompanied or unaccompanied by consciousness. With a well organized central nervous system we have a right to assume some higher functions than those concerned with a mere vegetative existence, and the conception of consciousness is merely a step beyond the conception of common sensations as they may be so readily studied in the laboratory. Huxley thinks that all the hereditary mental tendencies may justly be termed instincts, e. g., generosity; and he adjudges that art, music, seulpture, etc., may be considered nothing more than "innate potentialities." The best that we can say is that the boundaries between instinet and reason are very indefinite and obscure, and there seems to be good reason for relegating the entire problem to the realm of the unknowable, since more or less wild speculation is all that can come of any present efforts towards its solution. 


\section{SPIRITUALISM.}

This commonly discussed subject received from Huxley little more than passing notice because it did not appeal to him as resting upon an actual scientific basis. He says: "The only case of spiritualism I have had the opportunity of examining into for myself was as gross an imposture as ever came under my notice.* The only good that I can see in the demonstration of the truth of it is to furnish an additional argument against suicide."

That there is more than a chance relationship between many events occurring in actual daily experience is coming to be believed by careful psychologists everywhere. Yet one must be very careful how he states such beliefs else he will be thought overcredulous, or in league with the poor wretches who make a living by imposing on the ignorant and gullible. The laws of telopathy are, one may safely say, absolutely unknown to any human being and ignorance of such laws makes all the mouthings about occultism of the most foolish and ridiculous sort. Beyond doubt such a thing as thought transference does occur under exceptional conditions; but control over such trans-

* A careful report of this fake case was printed in the London Daily News for October 17 th, 1871. 
ference has never been obtained, and any one who pretends the ability to exercise such control is either a despicable charlatan or is of a morbidly imaginative frame of mind, a type removed only one degree from insanity. 
VIII.

CONCLUSION.

Having reviewed in a hasty manner the main teachings of Huxley as found in his writings there is left to us the further task of inquiring into the purposes and results of these teachings. What influence have they had upon the thought of our time?

I do not think that Huxley intended his word on any subject to be looked upon as final. He was a free thinker, and as such could not avoid expressing his views positively and emphatically on any subject which engaged his attention; but he must have realized that many of his dicta are open to grave challenge and would scarcely stand alone in the strong light of impartial criticism. However this may be it is encouraging in these days of halting between two opinions, when there seems to be so little which one can take as final, it is encouraging, I say, to find a man who has something positive to offer, especially when based upon a proper consideration of facts. It is sometimes better to be absolutely wrong than 
half-heartedly right, for in the former case it is possible to get back on a common ground of truth. In the latter, half-sayings often pass for the whole, and thus does the truth remain buried and error persist.

It may be objected that Huxley's philosophy of life was not of the most helpful and hopeful sort. This is, I think, sound criticism and true. There is surely very little in it that one can take and live by from day to day. It lacks the broad expansive outlook of the positive, it seems weak and vacillating. This is, I believe, the effect of deep-rooted agnosticism - because we do not know a thing should not prevent us from having faith in it, providing our faith is something more than tradition and possesses for us at least all the main elements of certainty. In his religious views Huxley surely lacks eren an humble guess about anything. He was content with saying he did not know because there was nothing tangible on which to base any argument good or bad; and without this he would not undertake to venture an opinion upon the greater questions.

His moral code, however, commends itself because of its nobility and sincerity. For him it was wholly and entirely satisfactory in the governing of his daily affairs. There was no question of creed or dogina but a plain statement of the golden rule, and the desire to live perfect in the sight of all men. One cannot 
help thinking that if his mind had been given to religious things he would have been an exemplar of piety and devotion. $\mathrm{He}$ had the essential passion without the constructive imagination of the truly devout. He could not believe in old-world prejudices and follies because he thought them untrue, however much spiritual comfort they might bring to others. His faith in humanity, however, was boundless. $\mathrm{He}$ believed that mankind was easily misled but not wilfully so, and that wrongdoing was most often due to ignorance of its results or to lack of restraint, causes both entirely remediable through mental and moral education. An early study of Carlyle had taught him the despicability of shams, hence he hated them with all the ardor of that great and peculiar intellect. Yet there was nothing in the world which he believed to be absolutely bad, for everything must have its place and purpose. It was simply man's duty to discover what that purpose entailed, and here was the basis of all true science.

In spite of his bent Huxley did not take much stock in the speculations of the philosophers, old or new. Plato he considered to be "The founder of all the vague and unsound thinking that has hindered philosophy, deserting facts for possibilities, and then after long and beautiful stories of what might be, telling you he doesn't believe them himself." As for 
the Renaissance philosophers, "It must be admitted," he says, "that though standing upon the shoulders of the older men, it was a long time before they saw as much as their forerumners had done." Yet he thought that the movement of modern philosophy is a hopeful one because it is reaching back toward the position of the old Ionians and is being clarified and strengthened by sound scientific ideas. "If I publish my criticism on Comte," he once said to his son, "I shall have to rewrite it as a summary of philosophical ideas from the earliest times. The thread of philosophical development is not on lines usually laid down for it. It goes from Democritus and the rest to the Epicureans and then to the Stoics, who tried to reconcile it with popular theological ideas just as was done by the Christian Fathers."

If Huxley failed in carrying out so much that he had planned to do upon what must his final claim to greatness rest? There is one thing, at least, that was mentioned in a general way in the introduction to this essay, which entitles him to distinction, and that is the versatility of his genius. The fourteen volumes he has left are monuments of his industry and knowledge, covering as they do such a vast range of subjects. One might ask if he did not attempt almost too much, since it is so difficult to do any one thing really well; but there stood 
a great range of possibilities and the temptation to explore new fields of thought was more than he could withstand. So far as one can see he carried through what he has recorded for us with enthusiasm and completeness. If he was not always wise in his methods he certainly was careful in their execution, and for this we owe him our thanks. Undoubtedly he would support with vigor our contention that the wisest among men is not always wise, and that the most foolish among men is sometimes wise; therefore one can afford to be lenient in criticising the results which he obtained. His work was that of an advanced scientific thinker who found it impossible to sum up anything finally and for all the future, yet it has a very important bearing on what shall come after and in this respect is of the pioneer order. Huxley was not so profound and untiring an investigator as Darwin, yet he was quicker perhaps in seeing how far-reaching Darwin's results were, and fully as capable of supporting them by illustrations and arguments. For his interest in the advancement of popular scientific thought all the world owes him a debt of gratitude, and hence he deserves an enduring place among the sons of light. 






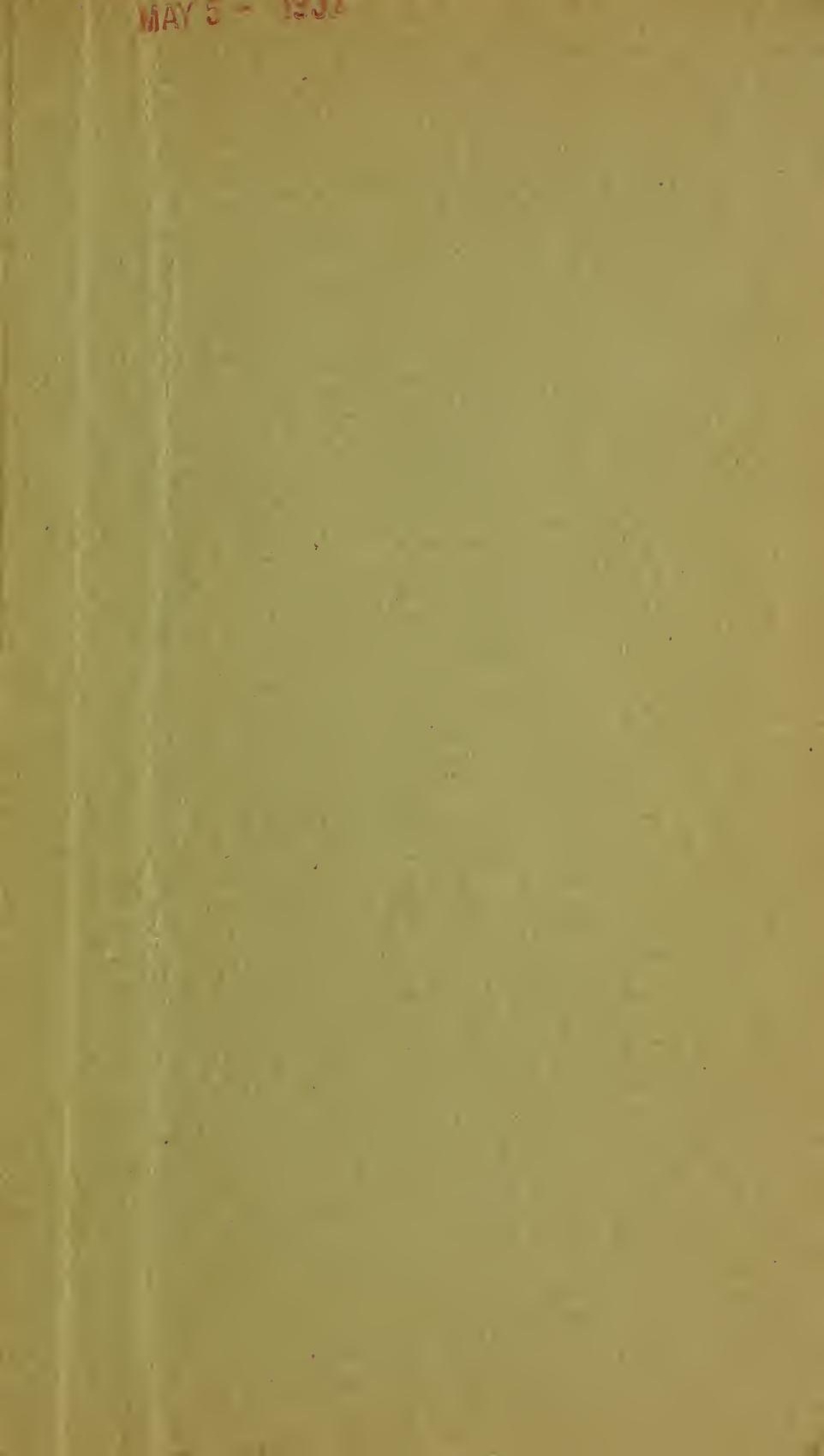


"

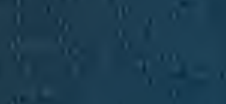

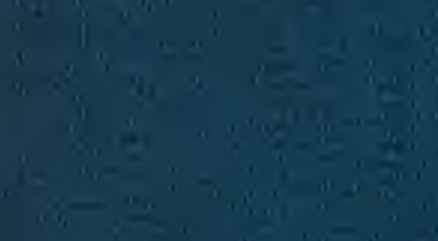

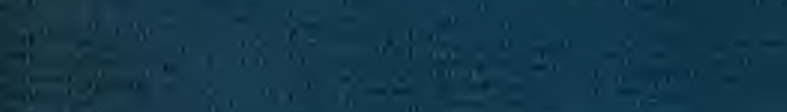

$x^{4}+20$

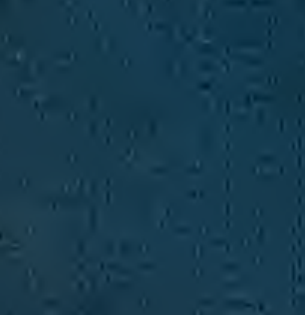
$2 \frac{1}{32} \cdot 2=$

- 6

$x^{\prime}+\frac{1}{1}$

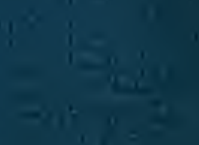

$\sqrt{7+2}+1$

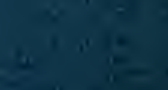

7

$\sqrt{1}$

$-2$

$1=$

(2) 11 